\title{
Effect of antibacterial nanocomposite film on the preservation of cheese
}

\author{
Yana $\mathrm{LI}^{1 \star}$ (D), Zhiwei CHEN ${ }^{1}$, Kaixuan WU ${ }^{1}$
}

\begin{abstract}
High density polyethylene (HDPE) and nano- $\mathrm{ZnO}$ were used to prepare nano- $\mathrm{ZnO} / \mathrm{HDPE}$ composite film with a nano-ZnO content of $0.5 \mathrm{wt} \%$. The morphology, mechanical, barrier and antibacterial properties, as well as the preservation to cheese of the films were studied. The results showed that the $\mathrm{ZnO}$ nanoparticles had a good dispersion in HDPE matrix so that the improvement of the mechanical, barrier and antibacterial performances of the film was achieved after the addition of nano- $\mathrm{ZnO}$ to HDPE. In comparison to cheese packaged in HDPE bags, it was found that the sensory score of the cheese in nano- $\mathrm{ZnO} / \mathrm{HDPE}$ bags increased from 66.6 to 73.7 and the $\mathrm{pH}$ of cheese was closer to the standard sample at storage time of $7 \mathrm{~d}$. Furthermore, nano-ZnO/HDPE inhibited effectively the increase of the total bacterial count (TBC) on cheese contrast of HDPE. That indicates the prepared nano- $\mathrm{ZnO} / \mathrm{HDPE}$ is potential in cheese packaging to extend the shelf life.
\end{abstract}

Keywords: $\mathrm{ZnO}$ nanoparticles; cheese; antibacterial; packaging.

Practical Application: Antibacterial film with excellent mechanical and barrier properties based on HDPE and nano$\mathrm{ZnO}$ for application of cheese products packaging.

\section{Introduction}

Cheese is a concentrated, fermented milk product that is produced by removing a large amount of water from milk and retaining the nutritional component. Its high protein content, however, makes it highly susceptible to bacterial attack and spoilage (Feeney et al., 2021; Woraratphoka et al., 2021). Currently, cheese preservation is mainly based on traditional refrigeration techniques, but this method requires equipment support and lacks flexibility (Appendini \& Hotchkiss 2002; Quintavalla \& Vicini, 2002).

In this regard, several attempts have been made to develop various physical and chemical preservation methods to reduce microbial contamination and improve the shelf life of these food products (Amjadi et al., 2019; Medeiros et al., 2014).

$\mathrm{ZnO}$ nanoparticles are inexpensive, naturally white, non-decomposable, non-discoloring and thermally stabl (Fang et al., 2006; Imazato, 2003). After Sawai et al. (1995) discovered in 1995 that $\mathrm{ZnO}$ powders have antibacterial properties against certain bacteria, an increasing number of scholars began to devote their research to the antibacterial properties of $\mathrm{ZnO}$. Moreover, these $\mathrm{ZnO}$ nanoparticles are approved by the Food and Drug Administration (FDA) and generally recognized as safe (GRAS) (Noshirvani et al., 2017).

The preliminary work of this experiment found that the $\mathrm{ZnO}$ nanoparticles/polymer composites not only had impressive mechanical properties and UV absorption, but also their antibacterial properties were excellent ( $\mathrm{Li} \& \mathrm{Li}, 2010$; Li et al., 2015). In this study, a nano-ZnO/HDPE composite film with a nano- $\mathrm{ZnO}$ content of $0.5 \mathrm{wt} \%$ (Optimum concentrations of
$\mathrm{ZnO}$ nanoparticles was determined according to our pre-tests to achieving the highest film properties without obvious aggregation of nanoparticles.) was used for packaging cheese and subsequently the preservation performance of the film on cheese was investigated. This was intending to expand the application of this film in food packaging, leading to a new technological approach being pursued for cheese preservation.

\section{Materials and methods}

\subsection{Materials}

High density polyethylene (HDPE) with Brand No. 5021d was provided from CNOOC and Shell Petrochemicals company Limited. Nano- $\mathrm{ZnO}$ (average particle size $50 \mathrm{~nm}$ ) was purchased from Shanxi Wenxiyaoxing Zinc Products Factory in China. $\gamma$-aminopropyltriethoxy silane (KH550) as a surface modifier was brought from Nanjing Shuguang Chemical Factory. Whole fat reconstituted cheese was from Inner Mongolia Yili Industrial Group. The other reagents were obtained from Tianjin North Tianyi Chemical Reagent Factory.

\subsection{Preparation of nano-ZnO/HDPE composite film}

The nano-ZnO was first pretreated with KH550, subsequently, the composite film (nano $\mathrm{ZnO}$ content $0.5 \mathrm{wt} \%$, thickness about $120 \mathrm{um}$ ) was generated using the melt blending method via a Haark mixing machine (Haark, Thremo Electro Instument, Germany), an extruder (Brabender Instument, Germany), a two rollers (SK-160B, Shanghai Rubber Machinery Factory, China), 
and a pressing machine (SL-45, Shanghai Rubber Machinery Factory, China). The preparation process is shown in Figure 1.

\subsection{Characterization of nano-ZnO/HDPE composite films}

Cross sections of nano-ZnO/HDPE composite films fractured in liquid nitrogen were observed with

a scanning electron microscope (SEM; JSM-6380, JEOL Inc., Japan) to observe morphology of the film.

An electronic universal testing machine (CMT4503, New Sans instrument, Shenzhen, China) was used to determine the mechanical properties of the nano- $\mathrm{ZnO} / \mathrm{HDPE}$ composite films at a crosshead speed of $200 \mathrm{~mm} / \mathrm{min}$ according to the standard of GB/T 16421-1996 and QB/T 1130-91. Six replicates were measured for each sample ( Li et al., 2020; Li et al. 2021).

The moisture permeability of film was measured according to the standard of GB 1037-88. The oxygen permeability was determined by using a Gas Permeameter (GDP-C, Brugger Feinmechanik GmbH, Germany). Three replicates were measured for each sample.

The antibacterial activities against Escherichia coli (E. coli) were determined by plate counting ( $\mathrm{Li} \& \mathrm{Li}, 2010)$. A $0.2 \mathrm{~mL}$ solution of bacteria $\left(2.0-5.0 \times 10^{6} \mathrm{cell} / \mathrm{mL}\right)$ was added onto the film surface and incubated for $24 \mathrm{~h}$. Then the bacteria suspension washed off from the film surface was plated onto nutrient broth agar to observe the colony forming units (CFU) of bacteria.

\subsection{Application of nano-ZnO/HDPE composite films in Cheese packaging}

\section{Cheese packaging}

Approximately $5 \mathrm{~g}$ of cheese was soaked in alcohol for 2 minutes. It was then transferred into bags $(8 \mathrm{~cm} \times 8 \mathrm{~cm})$ made of HDPE or nano-ZnO/HDPE films. The bags shown in
Figure 2 were thereafter sealed and stored at $23^{\circ} \mathrm{C}$ for 7 days before being tested for cheese quality. The cheese in original packaging stored at $5{ }^{\circ} \mathrm{C}$ was as the standard sample.

\section{Sensory evaluation}

The sensory evaluation was assessed by 20 semi-trained panelists (10 males and 10 females, 20-25 years old), which were not awarded of the experimental procedure. The cheese was scored according to Table 1 (Cattaneo et al., 2008), and the average score from twenty participants was taken as the final result (Ali et al., 2021; Delorme et al., 2021).

\section{pH value measurement}

An amount of cheese $(1.5 \mathrm{~g})$ was dispersed in deionized water $(40 \mathrm{~mL}$ ) with an ultrasonator (KQ-300DV, Kunshan, China) for 30 minutes. The $\mathrm{pH}$ value of the supernatant was measured with an acidity meter (PHS-25B, Dapu Instrument, Shanghai, China). Three replicates were measured for each sample.

\section{Microbiological analysis}

For assay the total bacterial count (TBC) in the samples, the cheese samples $(2 \mathrm{~g})$ were brought from the packaging bags with $50 \mathrm{ml}$ of saline and homogenized using a water bath oscillator (HZS-H, Harbin Donglian, China) at $150 \mathrm{r} / \mathrm{min}$ for $15 \mathrm{~min}$. The $1 \mathrm{~mL}$ of diluted homogenates solution (1:10) were spread for the total bacterial counts by plate count agar and incubated at $37^{\circ} \mathrm{C}$ for $24 \mathrm{~h}$ (Sani et al., 2017).

\section{Results and discussion}

\subsection{Morphology of nano-ZnO/HDPE composite film}

Figure 3 shows that after adding nano- $\mathrm{ZnO}(0.5 \mathrm{wt} \%)$ to HDPE, the $\mathrm{ZnO}$ particles were uniformly dispersed in matrix at the nanometer level with no large-area agglomeration.

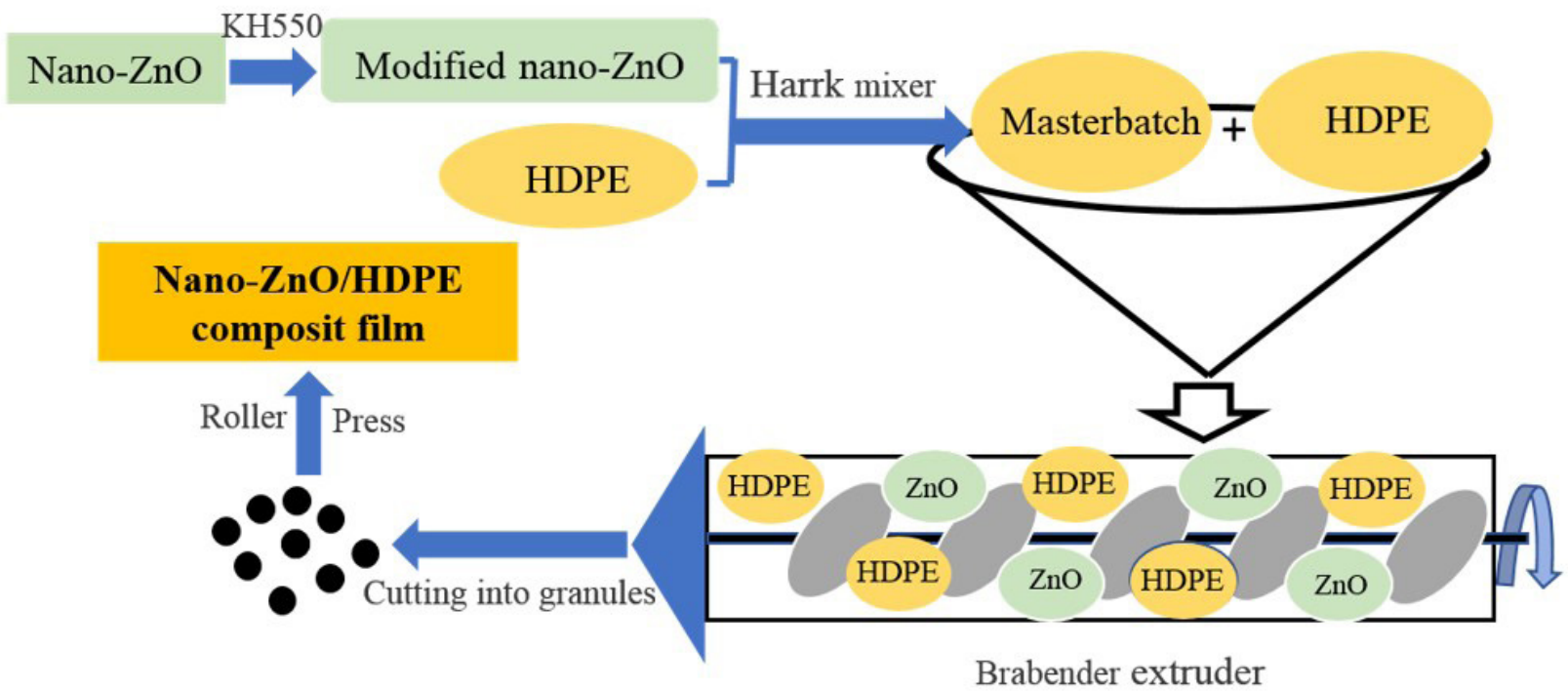

Figure 1. Preparation of nano- $\mathrm{ZnO} / \mathrm{HDPE}$ composites. 
Table 1. Quality evaluation of cheese.

\begin{tabular}{|c|c|c|}
\hline \multirow{2}{*}{ Rating criteria } & \multicolumn{2}{|c|}{ Rating range } \\
\hline & 0 points & 20 points \\
\hline Smell and taste & Taste musty, sour, bitter and other undesirable odors & $\begin{array}{l}\text { Tastes cheesy with a characteristic flavor, no unpleasant } \\
\text { smells }\end{array}$ \\
\hline Histological architecture & $\begin{array}{l}\text { Loose condition with cracks in the outer skin and sandy } \\
\text { sections }\end{array}$ & $\begin{array}{l}\text { Uniform and consistent texture, moderate softness, moist, } \\
\text { fine condition }\end{array}$ \\
\hline Melting and stringy & $\begin{array}{l}\text { Poor melting properties, more grease precipitation, not } \\
\text { stringy }\end{array}$ & $\begin{array}{l}\text { Good melting fluidity, no obvious grease precipitation and } \\
\text { stringy }\end{array}$ \\
\hline
\end{tabular}
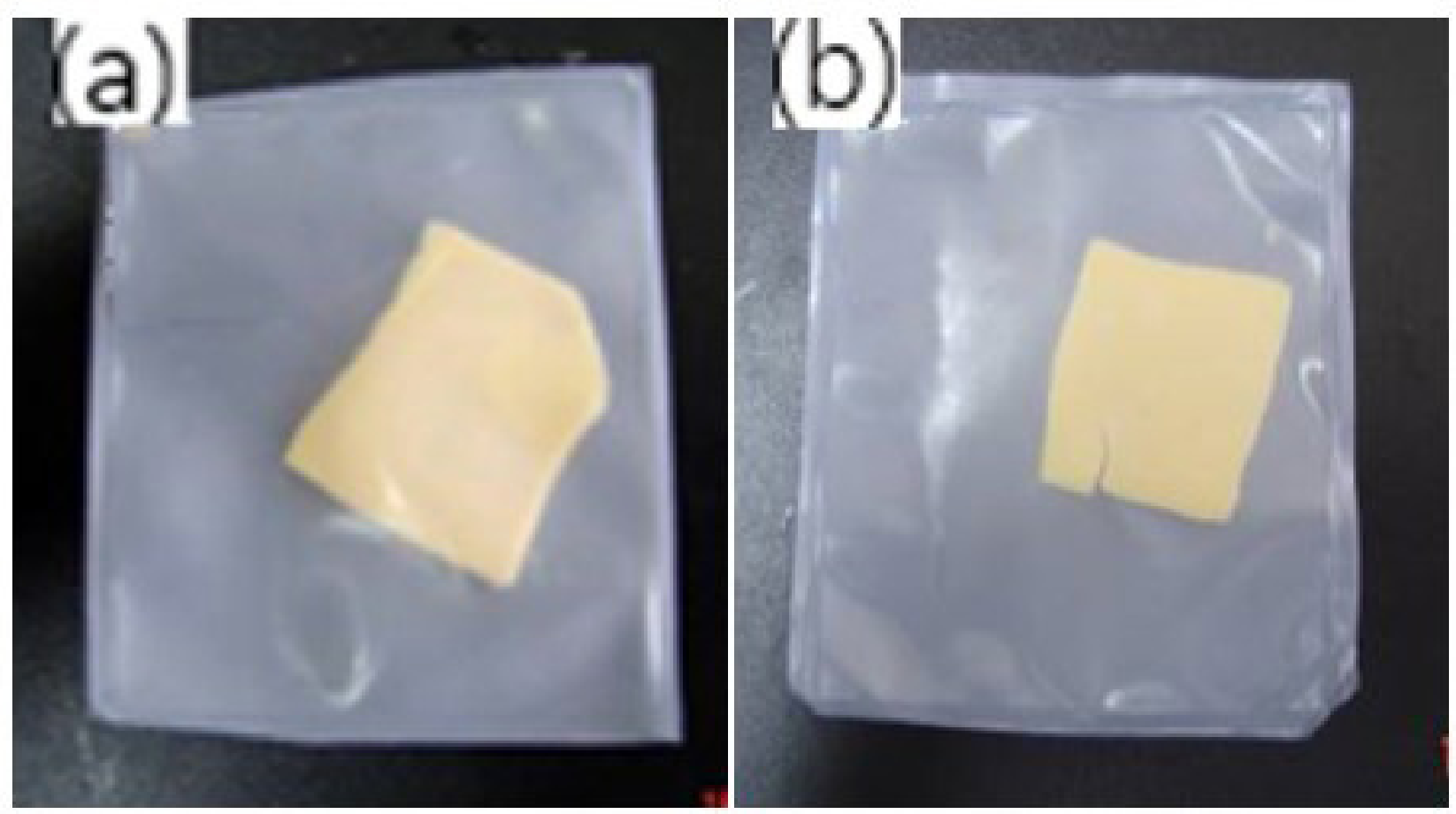

Figure 2. Cheese packaging, (a) HDPE film; (b) nano-ZnO/HDPE composite film.
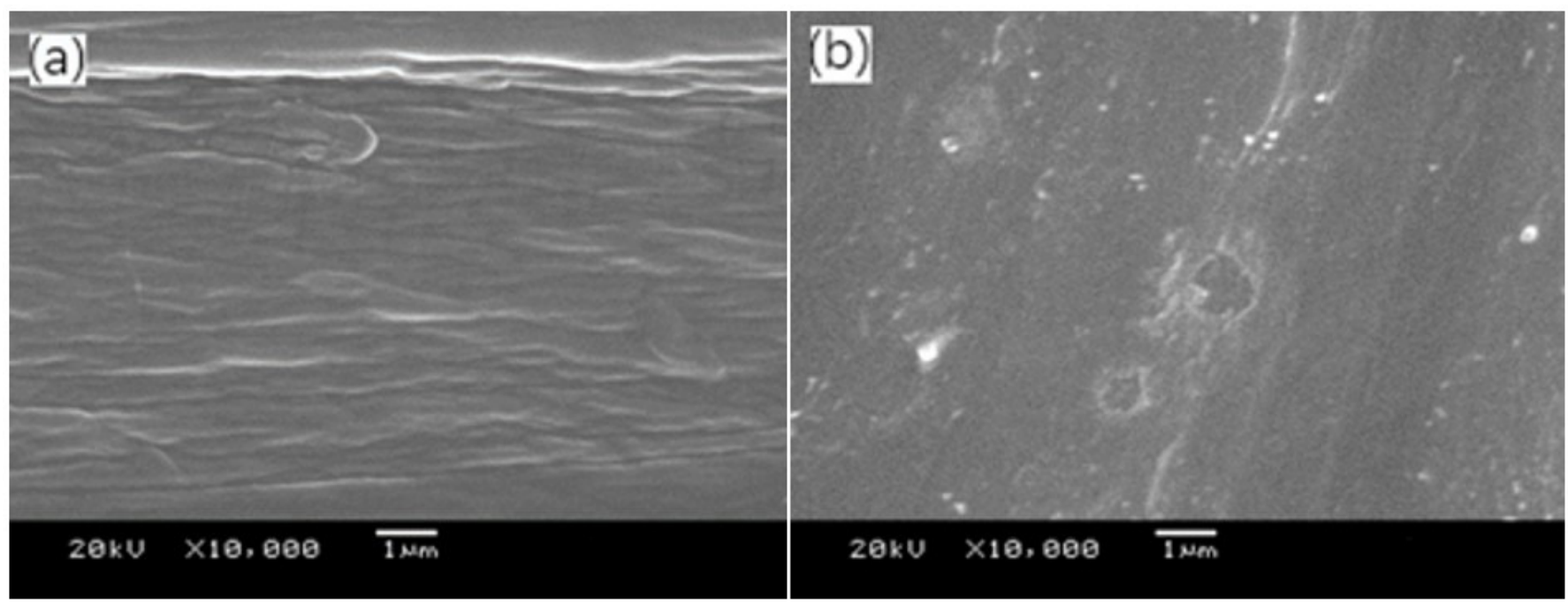

Figure 3. Cross-section morphology of HDPE (a) and nano-ZnO/HDPE composite film (b). 


\subsection{Mechanical and barrier properties of nano- $\mathrm{ZnO} / \mathrm{HDPE}$ composite film}

In Table 2, it can be deciphered that the mechanical properties and barrier properties of the nano- $\mathrm{ZnO} / \mathrm{HDPE}$ composite film were improved when the nano- $\mathrm{ZnO}$ content was only at $0.5 \%$. This was due to the fact that when a small amount of nano- $\mathrm{ZnO}$ was added, the nano- $\mathrm{ZnO}$ was better dispersed in the matrix. The small particle size and large specific surface area of the nanoparticles made it easier for strong interfacial interactions with the HDPE matrix. This effectively improved the fracture work required for crack extension and stop crack growth. In addition, as rigid particles, inorganic nanoparticles had the balancing effect of stress concentration and stress radiation. By absorbing the impact and radiation energy levels, the polymer had no obvious stress concentration phenomenon and achieved the mechanical equilibrium state of the composite material ( $\mathrm{Li}$ \& Li, 2010). Liu \& Jia (2011) reported that the tensile strength was the highest when nano- $\mathrm{ZnO}$ amount was $3 \%$ under the two-step, the tensile strength was increased up to about $22 \%$, and the fracture elongation rate was increased up to about $11 \%$. Chen et al. (Chen et al., 2021) reported that with the addition of $1.0 \mathrm{wt} \% \mathrm{Cu}-\mathrm{MOF}$, the tensile strength and elongation at break are increased to $45.7 \mathrm{MPa}$ and $2.4 \%$, respectively. On increasing the amount of $\mathrm{Cu}-\mathrm{MOF}$, the mechanical properties of the CA/ $\mathrm{Cu}-\mathrm{MOF}$ nanocomposite are further improved. In addition, the improved barrier performance of the nanocomposite film may have been due to the refinement of the HDPE grains because of the addition of $\mathrm{ZnO}$ nanoparticles ( $\mathrm{Li}$ et al., 2015).

\subsection{Antibacterial acitivity of nano-ZnO/HDPE composite film}

Figure 4 shows the colonies recovered on the films incubating with $E$. coli for $24 \mathrm{~h}$ 。 It was found that CFU amount of E. coli was dramatically reduced for nano- $\mathrm{ZnO} / \mathrm{HDPE}$ composite films in contrast with the HDPE films as control from Figure 4. That reveals that the addition of $\mathrm{ZnO}$ to HDPE endows favorable antibacterial activity of nano-ZnO/HDPE composite film. Research affirms (Jahed et al., 2017; Li \& Li, 2010) that nano-ZnO can produce antimicrobial properties through both zinc ion dissolution and photocatalytic generation of reactive oxygen species.

\subsection{Sensory evaluation of packaged cheese}

The sensory scores of cheese stored at $7 \mathrm{~d}$ were shown in Table 3. It can be seen that the total sensory scores of the cheeses packed with nano- $\mathrm{ZnO} / \mathrm{HDPE}$ film were higher than those of the cheeses packed with HDPE film. That indicated that the nano-ZnO/HDPE composite film had a effectively effect on the freshness of the cheeses. The sensory properties of the cheeses were notably improved after being packaged and stored for

Table 2. Properties of nano-ZnO/HDPE composite films.

\begin{tabular}{cccccc}
\hline & \multicolumn{3}{c}{ Mechanical properties } & \multicolumn{2}{c}{ Barrier properties } \\
\hline Nano-ZnO/\% & Tensile strength /MPa & Elongation at break $/ \%$ & Tear strength /MPa & $\begin{array}{c}\text { Oxygen permeability } \\
\text { coefficient } \times 10^{-14} /\left(\mathrm{cm}^{3} . \mathrm{cm} /\right.\end{array}$ & $\begin{array}{c}\text { Moisture permeability } \\
\text { coefficient } \times 10^{-13} \\
\left.\mathrm{~cm}^{2} . \mathrm{s} . P a\right)\end{array}$ \\
0 & & & & $8.80 \pm 0.7$ & $6.32 \pm 0.2$ \\
0.5 & $20.01 \pm 1.2$ & $746.63 \pm 7.2$ & $151.36 \pm 10.1$ & $8.08 \pm 0.8$ & $5.29 \pm 0.5$ \\
\hline
\end{tabular}
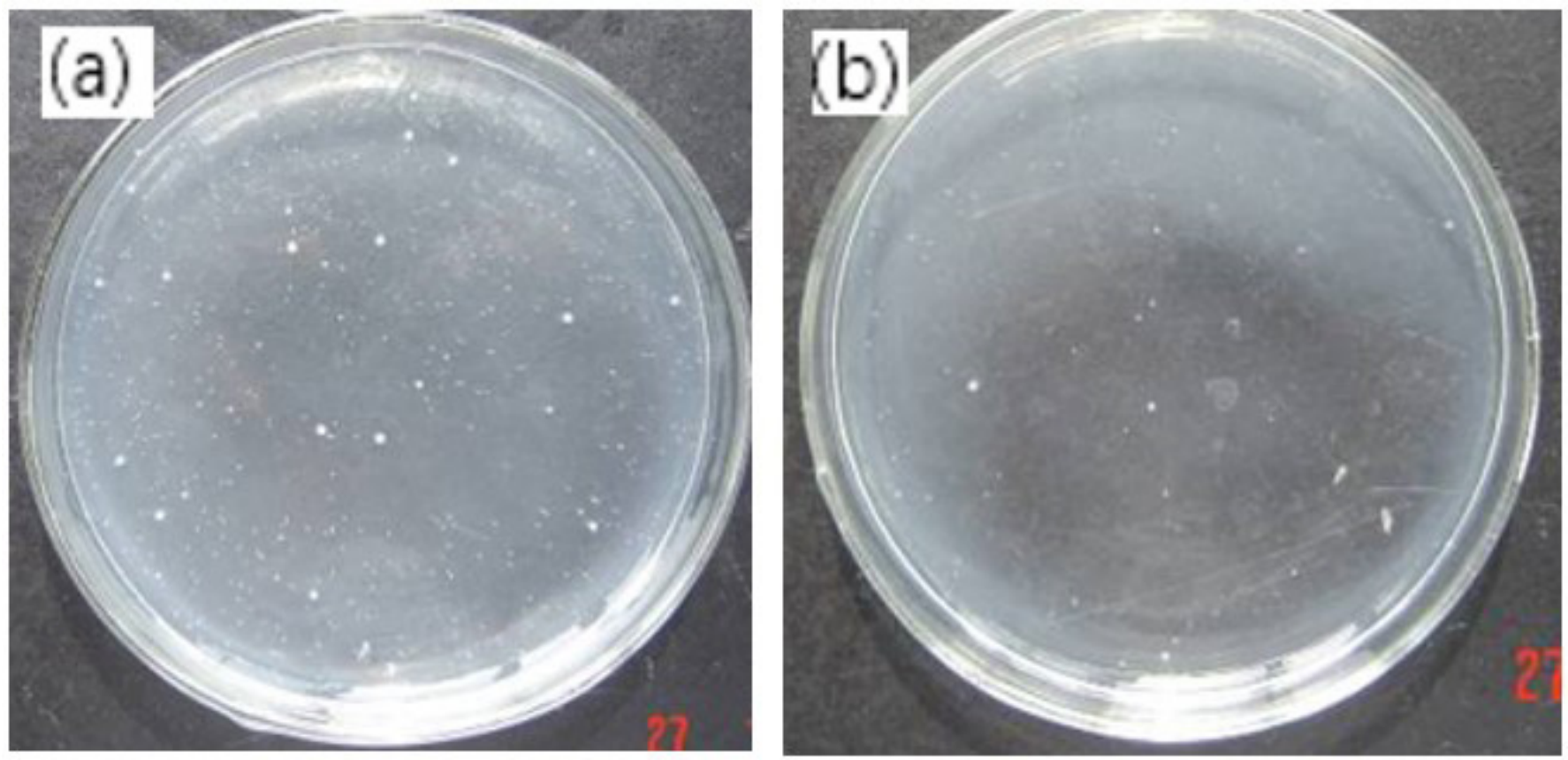

Figure 4. CFU of E. coli on the HDPE (a) and nano-ZnO/HDPE composite films (b). 
Table 3. Cheese quality on storage of $7 \mathrm{~d}$.

\begin{tabular}{cccc}
\hline samples & sensory scores & $\mathrm{pH}$ & $\mathrm{TBC}\left(\times 10^{4} \mathrm{CFU} / \mathrm{mL}\right)$ \\
\hline Standard & $81.5 \pm 2.3$ & $6.212 \pm 0.1$ & $0 \pm 0.1$ \\
HDPE & $66.6 \pm 6.2$ & $6.140 \pm 0.1$ & $8.2 \pm 0.1$ \\
nano-ZnO/HDPE & $73.7 \pm 3.4$ & $6.167 \pm 0.1$ & $3.2 \pm 0.1$ \\
\hline
\end{tabular}

several days, in comparison to the film without the addition of $\mathrm{ZnO}$ nanoparticles.

\section{$3.5 \mathrm{pH}$ value of packaged cheese}

Table 3 presents the $\mathrm{pH}$ of cheese samples on the storage time of $7 \mathrm{~d}$. In general, the $\mathrm{pH}$ of cheese decreases slightly at the beginning of spoilage, which might be attributed to the production of $\mathrm{CO}_{2}$ by microorganisms due to degradation of lactate and decarboxylation of amino acids at the cheese surface (Youssef et al., 2015, 2018). Moreover, reduction of the cheese $\mathrm{pH}$ reveals the presence of lipolysis, which is unfit for consumers (Singh et al., 2018).

As shown in Table 3, when the cheese was packed with the nano- $\mathrm{ZnO} / \mathrm{HDPE}$ film and left for 7 days, the $\mathrm{pH}$ of the cheese decreased relative to that of the standard cheese. Nevertheless, the decrease was less than that of the cheese wrapped in the pure HDPE film. This indicated that the nano-ZnO/HDPE composite film was more effective in preserving the cheese than the pure HDPE film.

\subsection{Microbial growth of packaged cheeses}

Table 3 illustrates that the packaged cheese was contaminated with microorganisms after being stored for 7 days, comparing with the standard sample. Furthermore, the bacteria for cheese packaged in the nano-ZnO/HDPE composite film was $3.2 \times$ $10^{4} \mathrm{CFU} / \mathrm{mL}$, significantly less than that of the HDPE film $(8.2 \times$ $10^{4} \mathrm{CFU} / \mathrm{mL}$ ) attributed to the antibacterial property of nano$\mathrm{ZnO} / \mathrm{HDPE}$. That suggests that the nano-ZnO/HDPE composite film had a preservative effect on cheese.

\section{Conclusion}

The nano-ZnO/HDPE composite film with a nano $\mathrm{ZnO}$ content of $0.5 \%$ was prepared by the melt blending method. The $\mathrm{ZnO}$ particles were uniformly dispersed in HDPE matrix. The mechanical, barrier and antibacterial properties of the composite film was dramatically improved compared to the HDPE film. The decrease of sensory and $\mathrm{pH}$ of cheese packaged with nano- $\mathrm{ZnO} / \mathrm{HDPE}$ was slower than that packaged with HDPE. The nano-ZnO/HDPE composite film also inhibited effectively the microbial growth of the cheese stored at $7 \mathrm{~d}$. These results indicate that the prepared nano-ZnO/HDPE composite film has potential application in preservative packaging for prolong the shelf life of cheese.

\section{References}

Ali, M. B., Murtaza, M. S., Shahbaz, M., Sameen, A., Rafique, S., Arshad, R., Raza, N., Akbar, Z., Kausar, G., \& Amjad, A. (2021). Functional, textural, physicochemical and sensorial evaluation of cottage cheese standardized with food grade coagulants. Food Science and Technology, 2061, 1-7.

Amjadi, S., Emaminia, S., Nazari, M., Davudian, S. H., Roufegarinejad, L., \& Hamishehkar, H. (2019). Application of reinforced $\mathrm{ZnO}$ nanoparticle-incorporated gelatin bionanocomposite film with chitosan nanofiber for packaging of chicken fillet and cheese as food models. Food and Bioprocess Technology, 12(7), 1205-1219. http://dx.doi.org/10.1007/s11947-019-02286-y.

Appendini, P., \& Hotchkiss, J. H. (2002). Review of antimicrobial food packaging. Innovative Food Science \& Emerging Technologies, 3(2), 113-126. http://dx.doi.org/10.1016/S1466-8564(02)00012-7.

Cattaneo, T. M. P., Tornelli, C., Erini, S., \& Panarelli, E. V. (2008). Relationship between sensory scores and near infrared absorptions in characterising bittop an italian protected denomination of origin cheese. Journal of Near Infrared Spectroscopy, 16(3), 173-178. http:// dx.doi.org/10.1255/jnirs.775.

Chen, K., Yu, J., Huang, J., Tang, Q., Li, H., \& Zou, Z. (2021). Improved mechanical, water vapor barrier and UV-shielding properties of cellulose acetate films with flower-like metal-organic framework nanoparticles. International Journal of Biological Macromolecules, 167, 1-9. http://dx.doi.org/10.1016/j.ijbiomac.2020.11.164. PMid:33253742.

Delorme, M. M., Pimentel, T. C., Freitas, M. Q., Cunha, D. T., Silva, R., Guimarães, J. T., Scudino, H., Esmerino, E. A., Duarte, M. C. K. H., \& Cruz, A. G. (2021). Consumer Innovativeness and perception about innovative processing technologies: a case study with sliced Prato cheese processed by ultraviolet radiation. International Journal of Dairy Technology, 74(4), 768-777. http://dx.doi.org/10.1111/14710307.12807.

Fang, M., Chen, J., Xu, X., Yang, P., \& Hildebrand, H. F. (2006). Antibacterial activities of inorganic agents on six bacteria associated with oral infections by two susceptibility tests. International Journal of Antimicrobial Agents, 27(6), 513-517. http://dx.doi.org/10.1016/j. ijantimicag.2006.01.008. PMid:16713190.

Feeney, E. L., Lamichhane, P., \& Sheehan, J. J. (2021). The cheese matrix: understanding the impact of cheese structure on aspects of cardiovascular health: a food science and a human nutrition perspective. International Journal of Dairy Technology, 74(4), 656670. http://dx.doi.org/10.1111/1471-0307.12755.

Imazato, S. (2003). Antibacterial properties of resin composites and dentin bonding systems. Dental Materials, 19(6), 449-457. http:// dx.doi.org/10.1016/S0109-5641(02)00102-1. PMid:12837391.

Jahed, E., Khaledabad, M. A., Almasi, H., \& Hasanzadeh, R. (2017). Physicochemical properties of carum copticum essential oil loaded chitosan films containing organic nanoreinforcements. Carbohydrate Polymers, 164, 325-338. http://dx.doi.org/10.1016/j. carbpol.2017.02.022. PMid:28325333.

Li, S. C., \& Li, Y. N. (2010). Mechanical and antibacterial properties of modified Nano-ZnO/High-Density Polyethylene composite films with a low doped content of Nano-ZnO. Journal of Applied Polymer Science, 116(5), NA. http://dx.doi.org/10.1002/app.31802.

Li, Y. N., Xu, W. M., \& Zhang, G. Q. (2015). Effect of coupling agent on Nano-ZnO Modification and Antibacterial Activity of ZnO/HDPE Nanocomposite Films. IOP Conference Series. Materials Science 
and Engineering, 87(1), 012054. http://dx.doi.org/10.1088/1757899X/87/1/012054.

Li, Y., Ren, J., Zhang, G., \& Li, X. (2021). High-barrier and antibacterial films based on PET/SiOx for food packaging applications. Food Science and Technology, 41(3), 763-767. http://dx.doi.org/10.1590/fst.37720.

Li, Y., Wang, Y., \& Li, J. (2020). Antibacterial activity of polyvinyl alcohol (Pva)/E-Polylysine Packaging films anthe effect on longan fruit. Food Science and Technology, 40(4), 838-843. http://dx.doi. org/10.1590/fst.19919.

Liu, J., \& Jia, S. S. (2011). Preparation and properties of LLDPE/EVA/ Nano-ZnO composites. Advanced Materials Research, 183-185, 1864-1868.

Medeiros, B. G. S., Souza, M. P., Pinheiro, A. C., Bourbon, A. I., Cerqueira, M. A., Vicente, A. A., \& Carneiro-da-Cunha, M. G. (2014). Physical characterisation of an alginate/lysozyme nano-laminate coating and its evaluation on 'coalho' cheese shelf life. Food and Bioprocess Technology, 7(4), 1088-1098. http://dx.doi.org/10.1007/ s11947-013-1097-5.

Noshirvani, N., Ghanbarzadeh, B., Mokarram, R. R., \& Hashemi, M. (2017). Novel active packaging based on carboxymethyl cellulosechitosan-ZnO NPs nanocomposite for increasing the shelf life of bread. Food Packaging and Shelf Life, 11, 106-114. http://dx.doi. org/10.1016/j.fpsl.2017.01.010.

Quintavalla, S., \& Vicini, L. (2002). Antimicrobial food packaging in meat industry. Meat Science, 62(3), 373-380. http://dx.doi.org/10.1016/ S0309-1740(02)00121-3. PMid:22061613.

Sani, A. M, Ehsani, A., \& Hashemi, M. (2017). Whey protein isolate/ cellulose nanofibre/ $\mathrm{TiO}_{2}$ nanoparticle/rosemary essential oil nanocomposite film: its effect on microbial and sensory quality of lamb meat and growth of common foodborne pathogenic bacteria during refrigeration. International Journal of Food Microbiology, 251, 8-14. http://dx.doi.org/10.1016/j.ijfoodmicro.2017.03.018. PMid:28376399.

Sawai, J., Igarashi, H., Hashimoto, A., Kokugan, T., \& Shimizu, M. (1995). Evaluation of growth inhibitory effect of ceramics powder slurry on bacteria by conductance method. Journal of Chemical Engineering of Japan, 28(3), 288-293. http://dx.doi.org/10.1252/jcej.28.288.

Singh, A., Khamrai, M., Samanta, S., Kumari, K., \& Kundu, P. P. (2018). Microbial, physicochemical, and sensory analyses-based shelf life appraisal of white fresh cheese packaged into PET waste-based active packaging film. Journal of Packaging Technology and Research, 2(2), 125-147. http://dx.doi.org/10.1007/s41783-018-0034-5.

Woraratphoka, J., Innok, S., Soisungnoen, P., Tanamool, V., \& Soemphol, W. (2021). $\gamma$-Aminobutyric acid production and antioxidant activities in fresh cheese by Lactobacillus Plantarum L10-11. Food Science and Technology, 2061, 1-8. http://dx.doi.org/10.1590/fst.03121.

Youssef, A. M., El-Sayed, S. M., El-Sayed, H. S., Salama, H. H., Assem, F. M., \& Abd El-Salam, M. H. (2018). Novel bionanocomposite materials used for packaging skimmed milk acid coagulated cheese (Karish). International Journal of Biological Macromolecules, 115, 1002-1011. http://dx.doi.org/10.1016/j.ijbiomac.2018.04.165. PMid:29723621.

Youssef, A. M., El-Sayed, S. M., Salama, H. H., El-Sayed, H. S., \& Dufresne, A. (2015). Evaluation of bionanocomposites as packaging material on properties of soft white cheese during storage period. Carbohydrate Polymers, 132, 274-285. http://dx.doi.org/10.1016/j. carbpol.2015.06.075. PMid:26256350. 